Michail Pazarskis', Grigorios Lazos ${ }^{2}$, George Drogalas ${ }^{3}$

\title{
ASSESSING THE IMPACT OF TAXATION ON MERGERS IN THE EU: THE CASE OF GREEK LISTED FIRMS
}

The study examines the merger effects on taxation in the EU by examining the accounting per-formance of listed firms in Greece. The results revealed that accounting performance do not have changed significantly due to the merger event. However, regarding the impact of the new Greek Income Tax Code (Law 4172/2013), according to the EU Merger Directive 2009/113, there is not evidence of some notable effect from the new legal framework related to tax on mergers.

Keywords: mergers; taxation; accounting performance; financial ratios; Greece.

Tab. 4. Lit. 30.

Peer-reviewed, approved and placed: 08.08.2019.

DOI 10.32752/1993-6788-2019-1-218-113-121

\section{Міхаіл Пазарскіс, Григоріос Лазос, Георгій Дрогалас ОЦІНКА ВПЛИВУ ОПОДАТКУВАННЯ НА ЗЛИТТЯ В ЄС: ПРИКЛАД ГРЕЦЬКИХ ФІРМ}

Дослідження вивчає вплив злиття на оподаткування в ЄС шляхом вивчення бухгалтерської діяльності перелічених у Греції фірм. Результати виявили, що результати бухгалтерського обліку суттєво не змінилися внаслідок події злиття. Однак, стосовно впливу нового грецького кодексу з податку на прибуток (Закон 4172/2013), заідно Директиви ЄС про злиття 2009/113, немає жодних доказів якогось помітного ефекту від нової правової бази, пов'язаної з податком на злиття.

Ключові слова: злиття; оподаткування; результати бухгалтерського обліку; фрінансові коефріцієнти; Греція.

\section{Михаил Пазарскис, Григориос Лазос, Джордж Дрогалас ОЦЕНКА ВЛИЯНИЯ НАЛОГООБЛОЖЕНИЯ НА СЛИЯНИЕ В ЕС: ДЕЛО ГРЕЧЕСКИХ КОМПАНИЙ}

В исследовании рассматривается влияние слияний на налогообложение в ЕС путем изучения эффективности бухгалтерского учета перечисленных фирм в Греции. Результаты показали, что результаты бухгалтерского учета существенно не изменились из-за слияния. Однако, что касается влияния нового греческого Кодекса о подоходном налоге (Закон 4172/2013), согласно Директиве EC о слияниях 2009/113, нет никаких свидетельств какого-либо заметного эффекта от новой правовой базы, связанной с налогом на слияния.

Ключевые слова: слияния; налогообложение; бухгалтерский учет; фринансовые показатели; Греция.

Introduction. The implementation of a new tax law is expected to have an impact on the tax burden on businesses and the decisions they are required to make, as well as on public revenue. This effect can be positive or negative, but it can also have a 'zero' result. On the other hand, the decision of two or more companies to merge is one of the most important decisions they could make, and is capable of creating sig-

\footnotetext{
$\mathrm{PhD}$ in Financial Accounting, Department of Business Administration, University of Macedonia, Greece

${ }^{2}$ Adjunct Assistant Professor, Department of Economics, International Hellenic University, Greece

${ }^{3} \mathrm{PhD}$ in Accounting and Auditing, Department of Business Administration, University of Macedonia, Greece

(C) Michail Pazarskis, Grigorios Lazos, George Drogalas, 2019
} 
nificant growth prospects for the new company to emerge. In order to rationalize the merger decision, several factors are considered by the parties involved. The impact of taxation on mergers is one of the most important factors. Therefore, the change in the tax framework relating to the merger process is of particular importance to the deci-sions that businesses are required to make, significantly affecting the overall outcome of this action. In Greek tax law defining the merger process, a significant change to the existing framework has recently been made in implementation of the relevant EU directive.

The aim of this study is the examination of taxation after mergers with financial ratios of all listed Greek firms on the Athens Exchange, for three-year-period before (2011-2013) and after the introduction of the new Greek Income Tax Code (Law 4172/2013), according to the EU Merger Directive 2009/113. Thus, the structure of the paper is as follow: Next section provides the theoretical background of the study (relevant legal framework and literature review). The following section describes the dataset and methodology of the present study. After that, next section presents the results. Final section concludes the paper.

\section{Theoretical background.}

Legal framework on mergers in Greece:

a. The current legal framework for mergers (Law 4172/2013 applicable from 1/1/2014). A "merger" under Law 4172/2013, which is according to the EU Merger Directive 2009/113, means any act whereby: (a) one or more companies (transferring companies), in their dissolution without liquidation, transfer all of their assets and liabilities to another existing company (recipient or absorbed company) in exchange for the issue or transfer to shareholders or partners the contributing securities (stocks) company of the recipient company capital, (b) two or more companies (transferring companies), in their dissolution without being liquidated, transfer all of their assets and liabilities to a company they set up (recipient company) in exchange for the issue or transfer to shareholders or partners the contributing securities company of the recipient company capital.

In the event of a merger, an additional payment may be made by the recipient company or companies in addition to the issue or transfer of securities, provided that the payment does not exceed ten percent $(10 \%)$ of the face value, or if no face value exists, ten percent $(10 \%)$ of the taxable value of the securities. The above provisions apply only if the transferring company (s) and the acquiring company (s) are tax res-idents of Greece and / or of another EU Member State.

Law 4172/2013, as regards mergers, has the following tax advantages:

The merger does not imply, at the time of the merger, any taxation of goodwill, calculated on the basis of the difference between the market value of the transferred assets and liabilities and their taxable value.

The recipient company shall depreciate the assets in accordance with the rules that would apply to the transferring company if the merger had not occurred. Also, may transfer the reserves and provisions made by the transferring company with the tax exemptions and conditions that would apply to the transferring company if the transfer had not taken place. The recipient company assumes the rights and obliga-tions of the transferring company in respect of these reserves and provisions. Moreover may transfer the losses of the transferring company, under the same condi- 
tions as would have been the case for the transferring company if the merger had not taken place. If the recipient company participates in the capital of the transferring company, it is exempt from tax on any goodwill arising from the cancellation of such participation.

These provisions apply to the transfer of assets and liabilities: (a) where there is a transfer of a branch or branches of business located in Greece or in another EU Member State, provided that the transferring and the recipient company are both tax residents of Greece, (b) if the transferring company is a tax resident of another EU Member State, and the recipient company is a resident of Greece, to the extent that after the merger the assets, liabilities, reserves, provisions and losses transferred are not connected with the permanent establishment of the receiving company outside Greece, $\mathrm{c}$ ) if the recipient company is a tax resident of another EU Member State. and the transferring company is a tax resident of Greece or of another EU member state, to the extent that after the merger the assets, liabilities, reserves, provisions and losses transferred are linked to a permanent establishment in Greece of the recipient company.

The shareholder or partner of the transferring company is not subject to tax on the goodwill it obtains as a result of the merger, except for the proportion correspon-ding to any cash payment. Also, the shareholder or partner shall not assign to the securities it receives in return a higher taxable value than the value of the securities exchanged immediately prior to the merger. The above provisions shall apply to a shareholder or a partner who, in the event of a merger, exchanges securities of the transferring company with securities of the recipient company, provided that: (a) the shareholder or partner is a tax resident of Greece, or (b) the shareholder or partner, who is not a tax resident of Greece, holds the securities of the contributor and holds the securities of the receiving company through a permanent establishment which he maintains in Greece.

b. Legal framework before implementation of Law 4172/2013 (before 1/1/2014) Prior to the implementation of Law 4172/2013, the legislative framework was defined by the provisions of Law 2190/1920, Legislative Decree $1297 / 1972$ and Law 2166/1993. In the event of a merger, the provisions of any of the above laws could be applied at the discretion of the parties concerned. In more detail, the provisions of these laws provided for the following:

Legislative Decree 1297/1972 does not allow mergers of domestic companies with a foreign company, while Law 2166/1993 allows the merger of a domestic public limited company or limited liability company with branches of foreign public limited companies or limited liability companies. In this case, these branches should have their permanent establishment within the Greek territory.

Law 2190/1920 imposes a tax on the concentration of capital (1\%) in the capi-tal of the company resulting from the transformation, after deducting previously the capital of the converting company or the total capital of the merging companies, cap-ital reserves or the retained earnings, as well as the goodwill of the revaluation of the transformed companies. By Legislative Decree 1297/1972 and Law 2166/1993 no tax is imposed on the concentration of capital on the resulting goodwill. This tax is imposed only in the event of a concentration of funds, that is, if an asset is con-tributed. 
Law 2190/1920 and Legislative Decree 1297/1972 require an assessment of the assets of the transformed companies, which is carried out by a special committee that estimates real values and for that reason usually results in goodwill. This goodwill is considered to be income from business activity, taxed under the general provisions of income tax. $n$ the case of Legislative Decree 1297/1972 the imposition of this tax is suspended until the time of dissolution of the business resulting from the merger, whereupon the goodwill is required to be shown separate in the business accounts. Contrary to Law 2166/1993, it is necessary to establish the property of the trans-formed companies in book values, as they appear in their books, which is carried out either by the Board of Certified Auditors or by the Tax Office, or by the committee referred to in Law 2190/1920 and for this reason, no goodwill arises and therefore is not subject to taxation.

Under Law 2190/1920 there is an obligation to pay any tax, in favor of the State or a third party, including the tax on the transfer of immovable property. This obliga-tion relates to the transfer of all assets, including movable assets. On the other hand, Legislative Decree 1297/1972 and Law 2166/1993 provide for exemption from any tax, in favor of the State or a third party, including property transfer tax, on transfer of all assets.

It is not possible to form tax-free reserves as an incentive for the merger, nor any other tax incentive under all three legislations. In addition, the tax-free reserves of development laws, formed by the merged entity, provided that they are trans-ferred to a reserve account in the merged entity, are not taxable at the time of the merger. Tax-free reserves from non-distributable profits, formed by the transformed companies, as they are transferred to the new company, are not subject to taxation at the time of the merger. In the valuation of the assets of the transformed compa-nies, the loss shown in their liabilities on the balance sheet cannot be transferred to the new company, since it will be deducted from the determined value of the net capitalized worth.

Literature review. Many past studies on post-merger performance that employed financial ratios or accounting data supported an improvement in the accounting performance after the M\&As (Mylonidis \& Kelnikola, 2005; Agorastos et al., 2011; Vijayakumar \& Sridevi, 2013; Oruc Erdogan \& Erdogan, 2014; Rao-Nicholson et al., 2016), while others claimed a decrease in the post-merger performance (Dickerson et al., 1997; Sharma \& Ho, 2002; Pazarskis et al., 2008; Marfo Oduro \& Kwaku Agyei, 2013; Strasek \& Gubensek; 2016), and some others concluded a 'zero' result or ambiguous results from the M\&As action (Healy et al., 1992; Ghosh, 2001; Srivastava \& Prakash, 2014; Ahmed \& Ahmed 2014; Rodionov \& Mikhalchuk, 2016; Pantelidis et al., 2018).

Furthermore, regarding the taxation effects and merger decision several studies have been conducted diachronically supported positive effects of taxation on accounting performance after mergers (Auerbach \& Reishus, 1987b; Belz et al., 2013), while others claimed negative effects or negative correlation between profits and taxation after merger or merger activity (Landsman \& Shackelford, 1995; Ayers et al., 2007), and some others concluded a 'zero' result or ambiguous results from the merger action (Breen, 1987; Auerbach \& Reishus, 1987a; Devos et al., 2008). 
Research design. Financial ratios (quantitative variables). The examination of accounting performance through financial statements is a better and safer path after merger decision for a firm (Healy et al., 1992; Ramaswamy \& Waegelein, 2003; Marfo Oduro \& Kwaku Agyei, 2013; Ahmed \& Ahmed, 2014; Oruc Erdogan \& Erdogan, 2014; Al-Hroot, 2016; Gupta \& Banerjee, 2017). Thus, the study examines main elements of financial statements on financial ratios. Examination of financial ratios and accounting measures from financial statements are widely accepted and applied regarding companies' merger decisions in general and precisely on taxation issues (Auerbach \& Reishus, 1987a; 1987b; Landsman \& Shackelford, 1995; Seetharaman et al., 2008; Becker \& Fuest, 2011; Belz et al., 2013). The financial ratios of the present study are presented in the following table.

Table 1. Financial ratios (quantitative variables), author's

\begin{tabular}{|l|l|l|}
\hline \multicolumn{1}{|c|}{ Variables } & \multicolumn{1}{|c|}{ Financial ratios } & \multicolumn{1}{c|}{ Analysis } \\
\hline ROA Before Taxes & Return on Assets (before taxes) & Profit/Loss Before Taxes / Total Assets \\
\hline$R_{\text {OE }}$ Before Taxes & Return on Equity (before taxes) & Profit/Loss Before Taxes / Shareholders' funds \\
\hline$R_{\text {A }}$ Afier Taxes & Return on Assets (after taxes) & Net Income / Total Assets \\
\hline$R_{\text {OE }}$ Affer Taxes & Return on Equity (after taxes) & Net Income / Shareholders' funds \\
\hline
\end{tabular}

Sample selection. We have chosen to study a sample of listed firms as their finan-cial statements are published online and they have been examined by certified inter-nal and external auditors. The financial ratios of the sample firms are computed from their financial statements. The merger events of our sample, the financial statements and any other data were received from the published data on the Athens Exchange's website.

To start with, from a sample of all mergers, the mergers of listed firms in the peri-od from 2011 to 2016 in Greece are tracked. Then, the firms that performed mergers in less than a one-year period before and after the examined merger event are exclud-ed. Also, some firms that have been de-listed from the ASE for various reasons (bank-ruptcy, not meeting the standards of the market, etc.) were excluded from this pre-liminary sample. Furthermore, from this preliminary sample are similarly excluded the firms in the financial services industry, which present special peculiarities in their financial ratios. Finally, our study analyses only thirty-two listed firms. A distribution of examined merger events per year is presented in the table 2 .

Table 2. Merger events by year and categorised before or after the new merger law in Greece, author's

\begin{tabular}{|c|c|c|c|}
\hline Year & $\begin{array}{c}\text { Mergers } \\
\text { per year }\end{array}$ & $\%$ & $\begin{array}{c}\text { Categorisation before or after the new merger } \\
\text { law in Greece }\end{array}$ \\
\hline 2011 & 6 & $19 \%$ & 1 \\
\hline 2012 & 3 & $9 \%$ & 1 \\
\hline 2013 & 4 & $13 \%$ & 1 \\
\hline 2014 & 4 & $13 \%$ & 2 \\
\hline 2015 & 6 & $19 \%$ & 2 \\
\hline 2016 & 9 & $28 \%$ & 2 \\
\hline Sum & 32 & $100 \%$ & $1=40 \%, 2=60 \%$ \\
\hline
\end{tabular}


Last, the analysis of sample firms is also presented in the following table (table 2) as 'Pre' or 'Post' of the new Greek Income Tax Code and regarding the fact that the provisions of articles 52 to 56 of the GITC - Law 4172/2013 shall apply to corporate restructuring made from 1 January 2014 onwards (Pazarskis et al., 2018). Thus, we examine the sample firms in two new different separate groups: 1: are characterised the firms with mergers in the Pre-GITC period (years 2011-2013) and 2: are charac-terised the firms with mergers in the Post-GITC period (years 2014-2016). There are thirteen firms in the Pre-GITC period and nineteen firms in the Post-GITC period.

Methodology. Evaluation of accounting performance after merger. The merger action of each firm from the sample is considered as an investment that is evaluated by the NPV criterion (if NPV 0, the investment is accepted). Based on this view-point, the study proceeds to its analysis and regards the impact of the merger action similar to the impact of any other positive NPV investment of the firm to its ratios over a specific period of time (Healy et al., 1992; Agorastos et al., 2011; Pazarskis et al., 2008; 2018; Pantelidis et al., 2018).

The financial ratios for each company of the sample over a one-year period before (year $t-1$ ) or after (year $t+1$ ) the merger events are calculated, and the mean from the sum of each financial ratio for the years $t-1$ is compared with the equiva-lent mean from the years $t+1$, respectively. In this study, the mean from the sum of each financial ratio is computed than the median, as this could lead to more accurate research results, and this argument is consistent with many other researchers diachronically: Neely \& Rochester, 1987; Sharma \& Ho, 2002.

The study does not include the year of merger event $(t=0)$ in the comparisons, because this usually presents a number of events with influence firm's accounting per-formance as one-time merger transaction costs, necessary for the deal (Healy et al., 1992; Oruc Erdogan \& Erdogan, 2014). Last, to test for difference in accounting per-formance in the post-merger period than in the premerger two independent sample mean t-tests for unequal variances are applied.

Mergers and impact of the EU Merger Directive, as adopted by the new Greek merg-er law. The Law of the Greek Income Tax Code (GITC) incorporated the EU Merger Directive 2009/113. The GITC describes the new general legal framework of the tax-ation for the merger decision in Greece. The EU Directive provides a European common framework for business taxation regarding company restructuring in EU and provides the opportunities for some merger transactions with capital gains that are not subject to tax from mergers. The provisions of articles 52 to 56 of the Law shall apply to corporate restructuring made from 1 January 2014 onwards.

In order to reveal any possible impact of the taxation at mergers in Greece, we examine the sample firms in two new different separate groups: the firms with merg-ers in the Pre-GITC period (years 2010-2013) and the firms with mergers in the Post-GITC period (years 2014-2015). There are twelve firms in the Pre-GITC period and six firms in the Post-GITC period. It is well known that mergers provide the oppor-tunity (after the unity of the merged firms) to carry over net operating losses and unused tax credits or depreciation new policies of the merged firms, with high impact on corporate performance (Breen, 1987; Pazarskis et al., 2018). To test any differ-ence, first we calculate the differences of post- to pre-merger size of any financial ratio and then we apply the Kruskal-Wallis test (a non-parametric method of one-way 
ANOVA on ranks) by considering as qualitative (categorical) variable the case of Pre-GITC and Post-GITC period, as described above.

Results. Evaluation of accounting performance after merger. The ratios $R O A_{\text {Before_taxes, }} R O E_{\text {Betore_taxes, }} R O A_{\text {Atter_Taxes, }} R O E_{\text {Atter_taxes }}$ that measures the accounting per-

formance of the sample firms are not statistically significant $(p>0.1)$. Thus, there is not any impact (positive or negative) from the merger event, even after the added tax-ation on $R O A$ and $R O E$. Our results are similar to many past studies that concluded a 'zero' result or ambiguous results from the merger event (Healy et al., 1992; Ghosh, 2001; Srivastava \& Prakash, 2014; Ahmed \& Ahmed 2014; Rodionov \& Mikhalchuk, 2016; Pantelidis et al., 2018). Also, our results do not support previous past studies on post-merger performance that supported an improvement in the accounting per-formance after mergers (Mylonidis \& Kelnikola, 2005; Agorastos et al., 2011; Vijayakumar \& Sridevi, 2013; Oruc Erdogan \& Erdogan, 2014; Rao-Nicholson et al., 2016) or even claimed a decrease in the post-merger performance (Dickerson et al., 1997; Sharma \& Ho, 2002; Pazarskis et al., 2008; Marfo Oduro \& Kwaku Agyei, 2013; Strasek \& Gubensek; 2016).

Table 3. Comparison results (t-tests) for pre- and post-merger performance in different periods, author's

\begin{tabular}{|l|c|c|c|c|c|c|}
\hline Variables & $\begin{array}{c}\text { Mean } \\
\text { post- } \\
\text { merger }\end{array}$ & $\begin{array}{c}\text { Mean } \\
\text { pre- } \\
\text { merger }\end{array}$ & $\begin{array}{c}\text { Mean } \\
\text { pre- } \\
\text { merger }\end{array}$ & $\begin{array}{c}\text { Mean } \\
\text { post- } \\
\text { merger }\end{array}$ & $\begin{array}{c}\text { Mean } \\
\text { pre- } \\
\text { merger }\end{array}$ & $\begin{array}{c}\text { Mean } \\
\text { post- } \\
\text { merger }\end{array}$ \\
\hline & \multicolumn{2}{|c|}{$\begin{array}{c}\text { All mergers } \\
(2011-2016)\end{array}$} & \multicolumn{2}{|c|}{ Pre-GITC (2011- } & Post-GITC (2014-2016) \\
\hline ROABefore Taxes & 0.0018 & 0.0037 & -0.0073 & -0.022 & 0.0080 & 0.0211 \\
\hline ROE Before Taxes & -3.4 & 0.56 & -6.4 & 1.36 & -1.40 & 0.021 \\
\hline ROA After Taxes & -0.0023 & -0.0077 & -0.0167 & -0.028 & -0.0015 & 0.0155 \\
\hline ROE Affer Taxes & -3.7 & 0.51 & -6.8 & 1.24 & -1.51 & 0.019 \\
\hline
\end{tabular}

Note: ${ }^{* * *},{ }^{* *},{ }^{*}$ : rejection of the null hypothesis at a significance level of $0.01,0.05,0.1$, respectively.

Mergers and impact of the EU Merger Directive, as adopted by the new Greek merger law. Regarding the taxation effects and merger decision, we calculate the difference between the ratios $R O A_{\text {Before_taxes, }} R O E_{\text {Before_taxes, }} R A_{\text {After_Taxes, }}, R O E_{\text {After_taxes }}$ and then

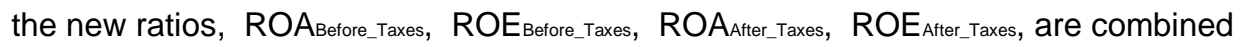
with the introduction of the new Greek Income Tax Code and regarding the fact that the provisions of articles 52 to 56 of the GITC - Law 4172/2013 (in accordance to the EU Merger Directive 2009/113).

However, none of them are statistically significant $(p>0.1)$, even the major-ity of them have improved. Our results are similar to many past studies that found a 'zero' result or ambiguous results from the merger action (Breen, 1987; Auerbach \& Reishus, 1987a; Devos et al., 2008). Furthermore, our results do not support previous studies that argued for positive effects of taxation on accounting performance after mergers (Auerbach \& Reishus, 1987b; Belz et al., 2013) or they claimed for negative effects or negative correlation between profits and taxation after merger or merger activity (Landsman \& Shackelford, 1995; Ayers et al., 2007). 
Table 4. Comparison results (Kruskal-wallis tests) of change on examined finan-cial ratios for GITC, author's

\begin{tabular}{|l|c|c|c|}
\hline \multicolumn{1}{|c|}{ Variables } & $\begin{array}{c}\text { Median } \\
\text { Pre-GITC }\end{array}$ & $\begin{array}{c}\text { Median } \\
\text { Post-GITC }\end{array}$ & $p$-value \\
\hline$\dot{a} R O A_{\text {Before Taxes }}$ & -0.009832 & 0.025921 & 0.212 \\
\hline$\dot{a} R O E_{\text {Before Taxes }}$ & -0.003394 & 0.011553 & 0.833 \\
\hline$\dot{a} R O A_{\text {After Taxes }}$ & -0.01001 & 0.02096 & 0.212 \\
\hline$\dot{a} R O E_{\text {After Taxes }}$ & 0.006245 & 0.004724 & 0.893 \\
\hline
\end{tabular}

Note: ${ }^{* * *},{ }^{* *},{ }^{*}$ : rejection of the null hypothesis at a significance level of $0.01,0.05,0.1$, respectively.

Conclusions and Directions for further investigation. The results of the research showed that the change in the tax framework, in the process of mergers, did not have a significant impact, based on the previous analysis of the financial ratios. In addition, as highlighted in the presentation of the tax framework, the most important difference of the new tax law is the transfer of the losses of the transferring companies and offsetting them with future profits of the recipient company, as opposed to the previous laws. Therefore, this significant change has not been able to affect remarkably the account-ing performance of businesses after the mergers, given the adverse economic conditions that the Greek economy was going through at that time during of an economic crisis.

Directions for further investigation of this study could examine the merger effects to a larger sample that could include not only merger-involved listed Greek firms, but also non-listed firms, even on different time periods. Also, apart from the impact of taxation, a future extension could be the examination from the industry relatedness's impact for the merged firms (thus, the existence of conglomerate merg-ers or non-conglomerates). Last, another future extension of this study could exam-ine the effects of the merger and the method of its financing.

1. Agorastos, A., Pazarskis, M. and Karagiorgos, T. (2011). An Accounting Comparison of the Post-Merger Economic Performance of Greek Acquiring Listed Firms in Domestic vs. International M\&As at South-East Europe, International Journal of Trade and Global Markets, 4(3), 328-342.

2. Ahmed, M., and Ahmed, Z. (2014). Mergers and Acquisitions: Effect on Financial Performance of Manufacturing Companies of Pakistan, Middle-East Journal of Scientific Research, 21(4), 706-716.

3. Al-Hroot, Y. A. K. (2016). The Impact of Mergers on Financial Performance of the Jordanian Industrial Sector. International Journal of Management and Business Studies, 6(1), 9-13.

4. Auerbach, A. and Reishus, D. (1987a). The Effects of Taxation on the Merger Decision, NBER Working Paper Series, Paper no. 2192.

5. Auerbach, A. and Reishus, D. (1987b). The Impact of Taxation on Mergers and Acquisitions, in A. Auerbach, ed., "Mergers and Acquisitions", NBER, 69-86.

6. Ayers, B., Lefanowicz, C. and Robinson, J. (2007). Capital Gains Taxes and Acquisitions Activity: Evidence of the Lock-in Effect, Contemporary Accounting Research, 24(2), 315-344.

7. Becker, J. and Fuest, C. (2011). Source versus Residence Based Taxation with International Mergers and Acquisitions, Journal of Public Economics, 95(1-2), 28-40

8. Belz, T., Robinson, L., Ruf, M. and Steffens, C. (2013). Tax Avoidance as a Driver of Mergers and Acquisitions, SSRN Papers, Paper no 2371706.

9. Breen, D. (1987). The Potential for Tax Gain as a Merger Motive: A Survey of Current Knowledge and Opportunities, FTC Bureau of Economics.

10. Devos, E., Kadapakkam, P.R. and Krishnamurthy, S. (2009). How Do Mergers Create Value? A Comparison of Taxes, Market Power, and Efficiency Improvements as Explanations for Synergies, Review of Financial Studies, 22(3), 1179-1211. 
11. Dickerson, A., Gibson, H. and Tsakalotos, E. (1997). The Impact of Acquisitions on Company Performance: Evidence from a Large Panel of U.K. Firms, Oxford Economic Papers, 49, 344-361.

12. Ghosh, A. (2001). Does operating performance really improve following corporate acquisitions?, Journal of Corporate Finance, 7, 151-178.

13. Gupta, B., \& Banerjee, P. (2017). Impact of merger and acquisitions on financial performance: Evidence from selected companies in India. International Journal of Commerce and Management Research, 3(1), 14-19.

14. Healy, P., Palepu, K. and Ruback, R. (1992). Does Corporate Performance Improve After Mergers?, Journal of Financial Economics, 31, 135-175.

15. Landsman, W. and Shackelford, D. (1995). The Lock in Effect of Capital Gains Taxes: Evidence from the RJR Nabisco Leveraged Buyout, National Tax Journal, 48, 245-259.

16. Marfo Oduro, I. and Kwaku Agyei, S. (2013). Mergers \& Acquisition and Firm Performance: Evidence from the Ghana Stock Exchange, Research Journal of Finance and Accounting, 4(7), 99-107.

17. Mylonidis, N. and Kelnikola, I. (2005). Merging Activity in the Greek Banking System: A Financial Accounting Perspective, South Eastern Europe Journal of Economics, 1, 121-144.

18. Neely, W. and Rochester, D. (1987). Operating Performance and Merger Benefits: The Savings and Loans Experience, Financial Review, 22(1), 111-129.

19. Oruc Erdogan, E. and Erdogan, M. (2014). Effect of Acquisition Activity on the Financial Indicators of Companies: An Application in BIST, International Journal of Business and Social Research, 4(7), 17-22.

20. Pantelidis, P., Pazarskis, M., Drogalas, G., \& Zezou, S. (2018). Managerial decisions and account-ing performance following mergers in Greece. Investment Management and Financial Innovations, 15(1), 263-276.

21. Pazarskis, M., Lyroudi, K. and Christodoulou, P. (2008). An Examination of the Long Run Performance of Greek Acquiring Firms, 15th Global Finance Conference (GFC 2008), Hangzhou, China.

22. Pazarskis M., Drogalas G., Koutoupis A. (2018). Mergers and Accounting Performance: Some Evidence from Greece during the Economic Crisis, Journal of Accounting and Management Information Systems, 17(1), pp. 31-45.

23. Ramaswamy, K. P. and Waegelein, J. (2003). Firm Financial Performance Following Mergers", Review of Quantitative Finance and Accounting, 20, 115-126.

24. Rao-Nicholson, R., Salaber, J. and Cao, T. H. (2016). Long-term performance of mergers and acquisitions in ASEAN countries", Research in International Business and Finance, 36(1), 373-387.

25. Rodionov, I. and Mikhalchuk, V. (2016). M\&A Synergies in Domestic M\&A Deals in Russia in 2006-2014", Russian Management Journal, 14(2), 3-28.

26. Seetharaman, A., Balachandran, M. and Saravanan, A. (2008). Accounting Treatment of Goodwill: yesterday, today and tomorrow, Problems and Prospects in the International Perspective, Journal of the Intellectual Capital, 5(1), 131-152.

27. Sharma, D. and Ho, J. (2002). The Impact of Acquisitions on Operating Performance: Some Australian Evidence, Journal of Business Finance \& Accounting, 29(1-2), 155-200.

28. Srivastava Ritu and Prakash Ajai (2014). Value creation through cross-border mergers and acqui-sitions by the Indian pharmaceutical firms, Journal of Strategy and Management, 7(1), 49-63.

29. Strasek, S., \& Gubensek, A. (2016). A pre- and post-acquisition performance of acquired firms in a small transition economy. Actual Problems in Economics, 4(2), 133-142.

30. Vijayakumar, A. and Sridevi, S. (2013). Analysis of operating efficiency of two and three wheeler sector of Indian automobile industry, International Journal of Management, IT \& Engineering, 3(10), 434-450. 